\title{
Comparison of SCORE-predicted risk of death due to cardiovascular events in women before and after menopause
}

\author{
Anna Piskorz ${ }^{1}$, Tomasz Brzostek² \\ 1Department of Nursing Care Management and Nursing Epidemiology, Institute of Nursing and Midwifery, Faculty of Health Sciences, \\ Jagiellonian University Medical College, Kraków, Poland \\ ${ }^{2}$ Department of Internal and Community Nursing, Institute of Nursing and Midwifery, Faculty of Health Sciences, Jagiellonian University \\ Medical College, Kraków, Poland
}

\begin{abstract}
Introduction: Approximately 55\% of women in Europe die from cardiovascular events, mostly as a result of coronary diseases and cerebral stroke. There is a 10-year shift in the cardiovascular risk between women and men. The risk in a 55-year-old female patient is similar to that of a 45 -year-old man, thus the risk among women increases rapidly around the age of 50, when menopause prevails to occur. The purpose of the study was to assess and compare the SCORE-predicted risk of a fatal cardiovascular incident in pre- and postmenopausal women.

Material and methods: The cross-sectional study was conducted as part of community nursing practice. It covered 219 women - inhabitants of Krakow, aged from 30 to 65, without clinically validated cardiovascular diseases of arteriosclerotic and/or diabetic origin, who volunteered to take part in the study. The group was divided into three subgroups: K1 - menstruating women $(n=113), \mathrm{K} 2 \mathrm{a}$ - women after natural menopause $(n=88)$, and K2b - women after surgical menopause $(n=18)$. The study made use of a lifestyle questionnaire, which concerned the social and economic status, and lifestyle habits including tobacco smoking. Arterial blood pressure was measured, and total cholesterol concentration in blood $(\mathrm{mmol} / \mathrm{l})$ was recorded.

Results: A high ( $\geq 5 \%$ ) level of the SCORE risk was discovered in $14.3 \%$ of postmenopausal women, as compared to $0.9 \%$ in the group of menstruating women. An average risk of a fatal cardiovascular incident during the following 10 years was significantly higher among women from groups K2a (2.61\%) and K2b (2.32\%) as compared to $\mathrm{K} 1$ - menstruating women (0.38\%). No difference was, however, discovered between groups of naturally (K2a) and surgically menopausal women (K2b).

Conclusions: A significantly higher risk of SCORE-predicted death caused by a cardiovascular incident, as compared to the group of women in the premenopausal period, is characteristic of women in the postmenopausal period.
\end{abstract}

Key words: cardiovascular risk, SCORE system, woman, menopause.

\section{Introduction}

Cardiovascular disease (CVD) is considered to be the most common cause of death among women in Europe. About $53 \%$ of female deaths are due to CVD, particularly coronary heart disease (CHD) and stroke [1]. Coronary heart disease mortality in women increases after the sixth decade of life. Most women become menopausal before this age [2]. More women than men die of CHD. More women have died from CVD than of cancer (including breast cancer), Alzheimer disease, chronic lower respiratory disease, and accidents combined [3]. The consequences of coronary artery disease (CAD) are worse in women than in men. Among individuals with premature myocardial infarction (MI) (under 50 years of age), women experience a twice-fold higher mortality rate after acute $\mathrm{Ml}$ compared to men [4].

The cardiovascular risk in women is shifted by 10 years as compared to men. Some publications show that the risk in 55-year-old women is similar to that in 45 -year-old men $[5,6]$. A low level of the absolute risk in a young, menstruating woman may obscure a high relative risk that would result in the absolute risk growing with age [7, 8]. Lowering CVD-related mortality in the recent years is more beneficial in the group of men than in women, in whom increased frequency of CVD continues to be reported, especially in older age cohorts $[5,6]$.

The guidelines (2003) of the European Society of Cardiology (ESC) introduced SCORE (Systemic Coronary 
Risk Evaluation), a risk assessment system based on results achieved in 12 European cohort studies involving 93,298 women. The strategy for coping with high-risk patients, in whom the risk exceeds $5 \%$, should aim at reducing the risk both with non-pharmacological and pharmacological methods [7].

Recommendations of the ESC in 2006 concerning CVD in women cover mainly the collection of epidemiological data on CVD and risk factors in women in different age ranges [8].

Hence the importance of a lifestyle change in order to avoid the high cardiovascular risk in the older age can be inferred. It is also required to direct both public health policy on the European and country level and in dividual contact between the healthcare professionals and patients, and also to include women in educational and motivational activities.

The goal of the studies was to assess and compare the risk of death due to SCORE-predicted cardiovascular incidents in the groups of women before and after menopause.

\section{Material and methods}

The research program covered 250 women inhabiting Krakow, who were included in the care of two family and community nursing practices operating in the Nowa Huta district. The respondent population consisted of women involved in the primary CVD prevention programme "Zdrowie dla Twojego Serca" [Health for your heart]. The following inclusion criteria were assumed: female gender, age in the range 30-65 years, no CVD or diabetes diagnosed or treated. The exclusion criteria were as follows: any previous CVD or diabetes diagnosis, taking cardiological medicines, age over 65 years or below 30 years, cognitive disorders precluding the patient from giving medical history. Only 219 women were qualified for the final analysis because of giving up or unsatisfactory co-operation of some patients.

The group was divided into premenopausal - K1 $(n=113)$ and postmenopausal - K2 $(n=106)$ subgroups of women, with the latter group being composed of 88 naturally (K2a) and 18 surgically menopausal women (K2b).

The study made use of a proprietary lifestyle questionnaire, which contained questions concerning the social and economic status, and lifestyle including tobacco smoking.

The arterial blood pressure measurements were carried out by means of S. Riva-Rocci method modified by Korotkov on the brachial artery of the left and right upper extremities with the use of dial (aneroid) sphygmomanometer. The measurements were carried out in patients at steady state, after at least 5 minutes of rest, in a sitting position. The measurements were repeated after an interval of 3 minutes [9]. In the analysis, the mean of two measurements was used. The venous blood samples were taken on after fasting (at least $12 \mathrm{~h}$ after the last meal) in the closed Vacutainer system according to the procedures and to the nurse practice standards [10]. The total cholesterol (TCh) ( $\mathrm{mmol} / \mathrm{l})$ was determined by the dry chemistry methodology with the use of VITROS 250 device in the Department of Clinical Immunochemistry of the Second Department of Medicine, Jagiellonian University Medical College.

The diagnostic survey has been performed with the use of original author's inventory on the menopause status and on using the hormone contraception or hormone replacement therapy.

Natural menopause was defined according to the World Health Organization (WHO) definition stating that menopause is the permanent cessation of menstruation resulting from the loss of ovarian follicular activity. Natural menopause is recognised to occur after 12 consecutive months of amenorrhea, for no other pathological or physiological cause [11].

The SCORE system, developed by the ESC on the grounds of cohort studies, was used to assess the risk of death in the coming 10 years. The system uses five risk factors, namely age, sex, systolic blood pressure, total cholesterol, and smoking to evaluate the total risk of death due to cardiovascular incidents in the following 10 years. Following the 2007 and 2012 guideline updates, the value of $\geq 5 \%$, deemed to justify introduction of a high-risk strategy, was assumed as the threshold of an elevated risk of death due to a cardiovascular incident. The SCORE chart for women in countries considered high-risk ones according to the European guidelines on cardiovascular prevention in clinical practice for 2012 was used [12, 13].

The data were analysed with the use of SPSS 14.0 and STATISTICA 6.1 PL packages. Variance analysis for differences between the groups was performed using post-hoc tests ( $F$ REGWi, Tamhane's T2). Probability at $p<0.05$ was considered statistically significant [14]. Sample size and statistical power analysis. The power analysis was performed in order to determine the statistical power (that is, the probability of obtaining a statistically significant effect, given that this effect exists in the population). The package GPower $[15,16]$ was used. Calculations were performed separately for the analysis of variance and the $\chi^{2}$ test. Cohen's [17] criteria for determining a small, medium and large effect size were used. The following results were obtained:

- for the ANOVA, the power to detect small (0.10), medium (0.25), and large (0.40) effect sizes was 0.24 , 0.91 , and 0.99 , respectively;

- for the $\chi^{2}$, the power to detect small (0.10), medium (0.30), and large (0.50) effect sizes was $0.18,0.96$, and 0.99 , respectively.

It must be borne in mind that in the above analyses, the assumption of equal sample sizes was not met. 
Therefore, the results should be treated with caution. Nevertheless, in general it follows that the power to detect significant effects was satisfactory in the case of medium and large effects, and somewhat smaller in the case of small effect sizes.

The study gained the approval of the Bioethical Committee of the Jagiellonian University (No. $\mathrm{KBET} / 242 / \mathrm{B} / 2002$ ). Participation in the study was voluntary, and participant anonymity was ensured.

\section{Results}

The average age of pre-menopausal women was $42.8 \pm 6.3$ years, and of postmenopausal women -55.4 \pm 4.9 years: $55.7 \pm 4.9$ years in naturally and $53.9 \pm$ 4.7 years in surgically menopausal women. The highest share (44.7\%) was women aged from 45 to 55 , followed by the $56-65$ and $36-44$ year brackets $(24.2 \%$ and $24.2 \%$, respectively). Women aged $30-35$ accounted for only $6.8 \%$ of the total.

A statistically significant age difference $(p<0.001)$ was identified between groups $\mathrm{K} 1$ and $\mathrm{K} 2 \mathrm{a}$, and $\mathrm{K} 1$ and $\mathrm{K} 2 \mathrm{~b}$, while groups $\mathrm{K} 2 \mathrm{a}$ and $\mathrm{K} 2 \mathrm{~b}$ did not differ significantly $(p=0.391)$. Age differences are presented in Table I.

The proportion of women currently smoking was higher (22\%) in the group of menstruating women (K1) than in the other two groups, $\mathrm{K} 2 \mathrm{a}$ and $\mathrm{K} 2 \mathrm{~b}$ (15.9\% and $16.6 \%$, respectively); however the differences between the groups were not statistically significant (Table I).

Increased systolic blood pressure $(\geq 140 \mathrm{mmHg}$ ) was observed in $14.2 \%$ of women. Compared to pre-meno- pausal women (K1), significantly higher systolic blood pressure levels were present both in naturally (K2a) and surgically (K2b) menopausal women, $p<0.001$ (Table I).

Compared with $\mathrm{K} 1$ women, women in $\mathrm{K} 2 \mathrm{a}$ and $\mathrm{K} 2 \mathrm{~b}$ groups had significantly higher average total cholesterol levels, $p<0.05$ (Table I).

The absolute risk score, according to the SCORE in the groups of pre- and post-menopausal women groups showed significant risk level differences ( $p<0.001)$. A high risk ( $\geq 5 \%$ ) was found in $14.3 \%$ of women in $\mathrm{K} 2$ as compared to $0.9 \%$ in $\mathrm{K} 1$ group.

The average 10-year risk of a fatal cardiovascular incident was significantly higher among K2a (2.61\%) and $\mathrm{K} 2 \mathrm{~b}(2.32 \%)$ women as compared to the menstruating women - K1 (0.38\%). No difference was, however, discovered between the group of naturally (K2a) and surgically (K2b) menopausal women (Table I).

\section{Discussion}

The present study uses the risk of death in the coming 10 years, as resulting from estimates based on SCORE studies, whose participants also included Poland, as a point of reference [7]. Following the recommendations of the Polish Forum for Prevention of Cardiovascular Diseases (PFP) [18], our study used the SCORE risk assessment system for high CVD risk countries. It showed that the risk of CVD-related fatality increases by the factor over fifteen between the groups of pre- and post-menopausal women. This statistically significant increase takes place in a period of 13 years, as the average age in the group of menstruating women

Tab. I. Comparison of selected risk factor for cardiovascular disease and level of risk SCORE in three groups of women (K1, K2a, K2b)

\begin{tabular}{|c|c|c|c|c|c|c|}
\hline \multicolumn{7}{|c|}{ Mean (X $\pm S D)$} \\
\hline Risk factors & $\mathrm{K} 1(n=113)$ & $\mathrm{K} 2 \mathrm{a}(n=88)$ & $\mathrm{K} 2 \mathrm{~b}(n=18)$ & $p$ & $F$ & $F$ REGW \\
\hline Age (years) & $42.81 \pm 6.32$ & $55.78 \pm 4.97$ & $53.94 \pm 4.78$ & $<0.001$ & 130.02 & $k 1-k 2 a, k 1-k 2 b$ \\
\hline $\begin{array}{l}\text { Systolic blood pressure } \\
\text { (SBP) (mm Hg) }\end{array}$ & $116.32 \pm 13.30$ & $129.55 \pm 18.29$ & $124.31 \pm 3.47$ & $<0.001$ & 18.12 & $k 1-k 2 a, k 1-k 2 b$ \\
\hline $\begin{array}{l}\text { Total cholesterol (Tch) } \\
(\mathrm{mmol} / \mathrm{l})\end{array}$ & $4.98 \pm 0.94$ & $5.68 \pm 1.03$ & $5.58 \pm 1.16$ & $<0.001$ & 12.86 & $k 1-k 2 a, k 1-k 2 b$ \\
\hline Smoking (declared) & $\mathrm{K} 1 ; n(\%)$ & $\mathrm{K} 2 \mathrm{a} ; n(\%)$ & $\mathrm{K} 2 \mathrm{~b} ; n(\%)$ & & & \\
\hline No, I've never smoked & $57(50.44)$ & $55(62.50)$ & $9(50.00)$ & & & \\
\hline Yes, I currently smoke & $25(22.12)$ & $14(15.91)$ & $3(16.67)$ & & & \\
\hline Yes, I used to smoke & $31(27.43)$ & 19 (21.59) & $6(33.33)$ & & & \\
\hline \multirow[t]{3}{*}{ Total } & $113 ; 100$ & $88 ; 100$ & $18 ; 100$ & 0.465 & & \\
\hline & \multicolumn{3}{|c|}{ Mean $(X \pm S D)$} & & & \\
\hline & $\mathrm{K} 1(n=113)$ & $\mathrm{K} 2 \mathrm{a}(n=88)$ & $\mathrm{K} 2 \mathrm{~b}(n=18)$ & $p$ & $\boldsymbol{F}$ & F REGW \\
\hline CVD risk 10 scores (\%) & $0.38 \pm 0.80$ & $2.61 \pm 3.58$ & $2.32 \pm 3.38$ & $<0.001$ & 20.40 & $k 1-k 2 a, k 1-k 2 b$ \\
\hline
\end{tabular}

$\mathrm{K} 1$ - menstruating women, $\mathrm{K} 2 \mathrm{a}$ - naturally post-menopausal women, $\mathrm{K} 2 \mathrm{~b}$ - surgically post-menopausal women

FREGW - test F Ryana-Einota-Gabriela-Welscha, CVD - cardiovascular disease 
was $42.8 \pm 6.3$ years, while among post-menopausal women it ranged from $55.4 \pm 4.9$ years (naturally menopausal women) to $53.9 \pm 4.7$ years (surgically menopausal women). It should be emphasised that the largest group among the patients comprised women aged from 45 to 55 years $(44.7 \%)$, i.e. the age when peri-menopausal hormonal changes and menopause occur [19].

Unlike in our research, in a study on 1168 people (including 765 women and 403 men) aged from 35 to 55 covered by primary health care in the Łomża and Kolno districts, Pędziński et al. claimed that the risk was low $<5 \%$ in all women, yet no account for the menopausal status of women in this study was done [20].

Our results are consistent with the recommendations published by the Polish Forum for Prevention concerning prevention of CVD and revealing that major CVD risk factors (arterial hypertension, dyslipidaemia, smoking, obesity, diabetes, low level of physical activities, and improper diet) are similar in women and men. However, the strength of correlation between individual factors and the CVD risk differs between two genders, e.g. diabetes more gravely increases the CVD risk in women than in men. The Polish Forum for Prevention indicated that recommendations for non-pharmacological and pharmacological prevention are also the same for men and women. The Forum emphasises that no hormone replacement therapy should be started and continued for the prevention of CVD in postmenopausal women [18].

SCORE-based interpretation of the cardiovascular risk in women requires attention paid to a number of significant elements. First, estimates of the value of an absolute CVD risk in peri-menopausal and early postmenopausal women may be underestimated due to the age shift between women and men, in prevalence of cardiovascular events, especially leading to death. Secondly, the low absolute risk of fatal events in the following 10 years, observed in the peri-menopausal period, may obscure a significant increase in the relative risk. That is why the Polish Forum for Prevention and the ESC consequently recommend using panels designed for 60-year-olds for this group. To illustrate changes in the lifestyle that contribute to risk reduction and mitigation of its escalation, taking place with age to a young person, relative risk tables can be used [7, $12,13,18]$. In this case, the European guidelines (2012) suggest that also the calculation of the individual's risk age can be beneficial. Additional factors that influence the cardiovascular risk (such as HDL cholesterol, glucose concentration, and body mass) can be covered via the HeartScore electronic risk assessment system (www.heartscore.org) [13]. Although the evaluation we present refers to an age group that is coherent with the age of the respondents, we discovered a fifteen times higher risk of death in the group of postmenopausal women. Thirdly, SCORE underestimates the risk in people with low HDL cholesterol levels, elevated triglycer- ides, impaired glucose tolerance, and high activity of inflammatory markers. These features are important components of the metabolic syndrome, which a number of authors believe to be the basic factor in determining the CVD risk in post-menopausal women [12, 21]. In our work we limited ourselves to present only the data covered by SCORE assessment.

The result of our study suggests that women in the peri-menopausal period, and especially after the menopause, should have been SCORE-assessed for the risk of developing CVDs and ensuing complications. The estimated individual absolute risk SCORE value may be helpful in undertaking necessary evidence-based prevention; as such risk is often underestimated in everyday practice [21].

The weaknesses of our study is the limited size of the sample and lack of random participant selection. It is so as the study involved only women interested in their health state.

We assume that the health situation among other women in the same age group, who were not interested in participation in this study, was not necessarily better. Generally, persons who take active interest in their health, are expected to live a healthier lifestyle.

On the other hand, the fact that selection to both the groups of women (i.e. before and after menopause) followed the same principles supports the reliability of the results presented.

Due to the lack of randomization (which, for obvious reasons, was not possible), the results should be treated with some caution. The study could have suffered from overrepresentation of patients after surgical menopause since such patients are more concerned about their health state than those menstruating or after natural menopause.

\section{Conclusions}

Presented results indicate that not only the intensity of symptoms of the climacteric syndrome, but also the cardiovascular risk should be assessed in women at menopausal age.

According to SCORE, a significantly higher risk of death resulting from cardiovascular incidents in the following 10 years is characteristic of women in the postmenopausal period as compared with premenopausal women.

Research suggests the need to include pre- and post-menopausal women, even without symptomatic CVD, in preventative actions in order to adjust their lifestyles and risk factors to the principles of primary CVD prevention.

\section{Disclosure}

Authors report no conflicts of interest. 


\section{References}

1. Nichols M, Townsend N, Scarborought P, et al. Cardiovascular disease in Europe: epidemiological update. Eur Heart J 2013; 34: 3028-3034

2. Arginier N, Couront M, Dallonngwille J, et al. Menopause and modifiable coronary heart disease risk factors: a population based study. Maturitas 2010; 65: 237-243.

3. Sharma K, Gulati M. Coronary heart disease in women: a 2013 update. Global Heart 2013; 8: 105-112.

4. Vaccarino V, Parsons L, Every NR, et al. Sex-based differences in early mortality after myocardial infarction. National Registry of Myocardial Infarction 2 Participants. N Engl J Med 1999; 341: 217-225.

5. Jarosz M, Kłosiewicz-Latoszek L, Charzewska J, et al. Diagnozowanie zaburzeń stanu odżywienia w praktyce lekarskiej i pielęgniarskiej. Instytut Żywności i Żywienia, Warszawa 2010; 1-25.

6. Podolec P, Kopeć G, Pająk A, et al. Ocena ogólnego ryzyka sercowo-naczyniowego. Forum Profilaktyki 2006; 2: 1-8.

7. Europejskie wytyczne dotyczące prewencji chorób sercowo-naczyniowych w praktyce klinicznej - wersja skrócona. Czwarta Grupa Robocza Europejskiego Towarzystwa Kardiologicznego i innych towarzystw do spraw prewencji chorób sercowo-naczyniowych w praktyce klinicznej. Kardiol Pol 2008; 66 (supl. I): S2-S5.

8. Choroby sercowo-naczyniowe $u$ kobiet. Stanowisko European Society of Cardiology. Medycyna Praktyczna 2006; 7-8: 27-49.

9. Wytyczne ESH/ESC dotyczące postępowania w nadciśnieniu tętniczym w 2013 roku. Grupa Robocza Europejskiego Towarzystwa Nadciśnienia Tętniczego (ESH) i Europejskiego Towarzystwa Kardiologicznego (ESC) do spraw postępowania w nadciśnieniu tętniczym. Kardiol Pol 2013; 71 (supl. III): S27-118.

10. Malinowska-Lipień I. Pobieranie krwi z żyły do badań biochemicznych. W: Procedury pielęgniarskie. Podręcznik dla studiów medycznych. Kózka M, Płaszewska-Żywko L (red.). PZWL, Warszawa 2009; 242-246.
11. World Health Organization. Research on the menopause in 1990s. Report of WHO Scientific Group. WHO Technical Report Series 866, Geneva 1996.

12. Europejskie wytyczne zapobiegania chorobom sercowo-naczyniowym w praktyce klinicznej. Aktualizacja 2007. Medycyna Praktyczna 2007; 12: 54-79.

13. Europejskie wytyczne zapobiegania chorobom sercowo-naczyniowym w praktyce klinicznej na rok 2012. Kardiol Pol 2012; 70 (supl. I): S1S100.

14. Stanisz A. Przystępny kurs statystyki w oparciu o program STATISTICA PL na przykładach medycyny. Stat Soft Polska, Kraków 1998.

15. Faul F, Erdfelder E, Lang AG, Buchner A. G*Power 3: A flexible statistical power analysis program for the social, behavioral, and biomedical sciences. Behavior Research Methods 2007; 39: 175-191.

16. Faul F, Erdfelder E, Buchner A, Lang AG. Statistical power analyses us ing $G^{*}$ Power 3.1: Tests for correlation and regression analyses. Behavior Research Methods 2009; 41: 1149-1160.

17. Cohen J. Statistical power analysis for the behavioral sciences. Academic Press, New York 1988.

18. Konsensus Rady Redakcyjnej Polskiego Forum Profilaktyki Chorób Układu Krążenia dotyczący profilaktyki chorób układu krążenia u kobiet. Forum Profilaktyki 2006; 3.

19. Karczmarek M. Określenie wieku menopauzy naturalnej w populacji polskich kobiet. Prz Menopauzalny 2007; 2: 77-82.

20. Pędziński B, Kurianiuk A, Pędziński W, et al. Ocena zagrożenia chorobami układu krążenia w oparciu o realizację programu profilaktyki w podstawowej opiece zdrowotnej. Probl Hig Epidemiol 2011; 92: 397-402.

21. Collins P, Rosano G, Casey C, et al. Management of cardiovascular risk in the peri-menopausal woman: a consensus statement of European cardiologist and gynaecologists. Eur Heart J 2007; 28: 2028-2040. 